\title{
Netralitas Aparatur Sipil Negara dalam Pemilihan Gubernur Riau Tahun 2018
}

\author{
Oleh: Birman Simamora \\ Dosen Fakultas Hukum Lancang Kuning \\ Jalan Yos Sudarso Km 8, Rumbai, Kota Pekanbaru, Indonesia
}

\begin{abstract}
Abstrak
Tujuan penelitian ini untuk menjelaskan netralitas Aparatur Sipil Negara dalam pemilihan Gubernur Riau tahun 2018. Jenis penelitian ini hukum sosiologis dengan pendekatan yuridis empiris dengan maksud untuk menjelaskan netralitas Aparatur Sipil Negara dalam pemilihan Gubernur Provinsi Riau tahun 2018 termasuk hambatan dan upaya mengatasinya. Netralitas Aparatur Sipil Negara dalam pemilihan Gubernur Riau tidak berjalan sepenuhnya. Ketidaknetralan terjadi sebelum masuk masa kampanye dan selama masa kampanye. Adapun bentuk ketidaknetralan, seperti menghadiri acara deklarasi, syukuran dan acara di kediaman pasangan calon tertentu. Pengerahan Aparatur Sipil Negara agar berpihak terhadap salah satu kandidat tidak ada ditemukan dalam pemilihan umum gubernur Riau tanggal 27 Juni 2018 yang lalu. Faktor penghambat netralitas Aparatur Sipil Negara dalam pemilihan Gubernur Riau disebabkan pengaruh tekanan (intervensi) dari calon pertahana. Upaya mengatasi agar Aparatur Sipil Negara tetap netral dalam pemilihan Gubernur Riau dapat dilakukan dengan memberikan sanksi sesuai PP Nomor 53 Tahun 2010 tentang Displin Pegawai Negeri Sipil.
\end{abstract}

\section{Kata Kunci: Netralitas, Aparatur Sipil Negara, Pemilihan}

\begin{abstract}
The purpose of this study is to explain the neutrality of the State Civil Apparatus in the election of the Governor of Riau in 2018. This type of research is the law of sociology with an empirical juridical approach with the intent to explain the neutrality of the State Civil Apparatus in the election of the Governor of Riau Province in 2018 including obstacles and efforts to overcome them. The neutrality of the State Civil Apparatus in the election of the Governor of Riau was not fully implemented. Non-neutrality occurs before entering the campaign period and during the campaign period. The forms of non-neutrality, such as attending a declaration, thanksgiving and events at the residence of certain candidate pairs. The deployment of the State Civil Apparatus in favor of one candidate was not found in the Riau governor general election last June 27 2018. Factors inhibiting the neutrality of the State Civil Apparatus in the election of the Governor of Riau were due to the influence of pressure (intervention) from prospective candidates.
\end{abstract}

*Penulis korespondensi e-mail: birman@unilak.ac.id 
Efforts to overcome so that the State Civil Apparatus remains neutral in the election of the Governor of Riau can be done by giving sanctions in accordance with Government Regulation Number 53 of 2010 concerning Discipline of Civil Servants.

\section{Keywords: Neutrality, State Civil Apparatus, Election}

\section{Pendahuluan}

Isu politik menjadi hal yang selalu diperbincangkan masyarakat dalam kehidupan sehari-hari.Pembicaraan tersebut terkadang terkait isu birokrasi yang dilatarbelakangi oleh kepentingan dan kekuasaan politik tertentu. Kekuasaan tertinggi dalam pemerintahan diseluruh dunia memang diperoleh melalui proses politik, termasuk juga di Indonesia. Untuk menentukan kepala negara dan kepala daerah dan wakilnya dilalui melalui proses politik dengan mekanisme pemilihan umum (pemilu). Mekanisme tersebut untuk menghasilkan penyelenggara pemerintahan negara termasuk penyelenggaraan pemerintahan daerah harus dilakukan dengan prinsip-prinsip demokrasi. ${ }^{1}$

Pemilu secara langsung di Indonesia untuk memilih presiden dan wakil presiden pertama kalidilaksanakan pada tahun 2004, sedangkan untuk pemilihan umum kepala daerah (pemilukada) pertama kali dilaksanakan tahun 2005. Pemilukada itu dilaksanakan berdasarkan Undang-Undang Nomor 32 Tahun 2004 tentang Pemerintahan Daerah. Pemilukada pertama di Kabupaten Kutai Kartanegara pada tanggal 1 Juni $2005 .{ }^{2}$
Pemilu langsung merupakan produk demokrasi, diharapkan sebagai solusi pasca rezim Orde Baru yang cenderung mengikat kebebasan dalam berbagai aspek kehidupan, terutama dalam aspek politik. Pemilu langsung menawarkan kebebasan bagi masyarakat untuk menentukan pilihan terhadap pemimpin negara dan daerah. Praktik kecurangan dalam pemilu langsung menjadi dilematis bagi elit dalam mencapai kekuasaan. Isu kecurangan dalam proses pemilukada bukan hanya dilakukan oleh aktor/pasangan calon dan tim pemenangannya, bahkan melibatkan kekuasaan birokrasi. Penggunaan kekuasaan birokrasi, seperti Aparatur Sipil Negara terlihat jelas pemanfaatannya sebagai kekuatan politik. Hal ini dikarenakan Aparatur Sipil Negara dikendalikan langsung oleh pejabat politik, seperti kepala daerah (gubernur dan bupati atau walikota) khususnya pasangan calon incumbent/petahana. Praktik mobilisasi Aparatur Sipil Negara dilakukan dengan rapi dan tersembunyi sehingga menyulitkan Badan Pengawas Pemilu (BAWASLU) dalam melakukan pengawasan. $^{3}$

Jabatan pemerintah yang berasal dari jabatan politik bisa menimbulkan

\footnotetext{
${ }^{1}$ Afan Gaffar, Pembangunan Hukum dan Demokrasi dalam Moh. Busro Muqaddas dkk (Penyunting), Politik Pembangunan Hukum Nasional, (Yogyakarta: UlI Press, 1992), hlm. 106.

${ }^{2}$ http://www.forumbebas.com/tread49484.html, diakses tanggal 9 Februari 2018.

${ }^{3} \mathrm{http}$ ://lampost.co/berita/pilgub-bawaslu-temupasalkan-ribuanpelanggaran,diakses tanggal 4 Februari 2018.
} 
kepentingan-kepentingan lain yang dapat mengganggu sistem birokrasi. Kepentingan politik tertentu atau kepentingan partai politik yang masuk dalam sistem birokrasi akan mengganggu asas kepegawaian, seperti netralitas Aparatur Sipil Negara yang dahulu disebut pegawai negeri sipil (PNS). Sebaiknya, pejabat politik yang sudah menduduki jabatan dalam pemerintahan, melepaskan jabatan politik didalam partainya sendiri. ${ }^{4}$

Pelaksanaan pemilukada diseluruh daerah memaksa publik peduli terhadap penyelenggaraannya. Hal ini karena terpolari-sasinya Aparatur Sipil Negara oleh partai politik yang berkuasa sehingga netralitas Aparatur Sipil Negara menjadi faktor utama berbagai kecurangan. ${ }^{5}$ Mengapa demikian? Ada beberapa faktor yang dapat mempengaruhi netralitas Aparatur Sipil Negara dalam pemilu, terutama pada faktor pekerjaannya sebagai pegawai birokrasi yang dikendalikan oleh jabatan politik.

Pertama, transaksi jabatan merupakan kebiasaan buruk birokrasi Indonesia, para pasangan calon melakukan lobi kepada pejabat-pejabat birokrat yang mereka anggap bisa mempengaruhi pegawainya untuk mendukung pasangan calon tersebut. Cara ini tentu saja bukan tanpa jasa, pasangan calon menjanjikan kedudukan/ jabatan yang lebih tinggi untuk keme- nangannya. Kedua, faktor kekuasaan dan kewenangan, hal ini menjadi penting karena pejabat birokrasi sering menyalahgunakan kekuasaan dan kewenangannya untuk keuntungan pribadi.

Pernyataan diatas beralasan, sebab menurut Pasal 130 ayat (1) dan ayat (2) Undang-Undang Nomor 32 Tahun 2004 tentang Pemerintahan Daerah, menyatakan bahwa pengangkatan, pemindahan, dan pemberhentian dari dan dalam jabatan eselon II pada pemerintahan daerah provinsi ditetapkan oleh gubernur, sedangkan pengangkatan, pemindahan, dan pemberhentian dari dan dalam jabatan eselon II pada pemerintah daerah kabupaten atau kota ditetapkan oleh bupati atau walikota setelah berkonsultasi kepada gubernur. ${ }^{6}$ Berdasarkan ketentuan itu, loyalitas Aparatur Sipil Negara kepada kepala daerah akan menjadi lebih besar. Selain itu, sering pula terjadi oknum Aparatur Sipil Negara melakukan kegiatan politik atas keinginan pribadi dikarenakan naluri untuk mendapatkan kedudukan serta pangkat yang tinggi.

Netralitas merupakan bentuk sikap dan tindakan untuk tidak terlibat pada suatu urusan atau masalah yang seharusnya tidak perlu dicampuri. Azhari "menjelaskan netralitas birokrasi merupakan kondisi terlepasnya birokrasi sipil sistem yang berarti birokrasi bekerja berdasarkan profesionalisme dan kemampuan teknis yang

${ }^{4}$ Miftah Thoha, Birokrasi Pemerintahan dan Kekuasaan di Indonesia, (Yogyakarta: Thafa Media, 2012), hlm. 7 .

${ }^{5}$ Muhammad Alwan Yamin, Netralitas Pegawai Negeri Sipil dalam Pemilihan Umum Kepala Daerah di Kabupaten Takalar, (Makasar: Universitas Hasanuddin, 2013), hlm. 3.

${ }^{6}$ Riris Katharina, Netralitas Birokrasi dalam Pemilu Legislatif 2009 (Studi di Kabupaten Labuhan Ratu), Jurnal IImiah, edisi kajian, 2010, hIm. 16. 
dibutuhkan".7 Netralitas Aparatur Sipil Negara ini erat kaitannya dengan intervensi calon pertahana.

Intervensi pada kegiatan birokrasi dan politik menurut Azhari bahwa "intervensi politik yang dimaksud merupakan upaya yang dilakukan oleh pejabat politik dalam mempengaruhi proses rekrutmen dan promosi birokrat pada jabatan jabatan birokrasi". ${ }^{8}$ Azhari juga menjelaskan "intervensi politik terhadap birokrasi adalah tindakan yang dilakukan oleh pejabatpejabat politik yang tidak sejalan dengan semangat netralitas birokrasi dan aturan perundangan yang berlaku dalam manajemen birokrasi publik". ${ }^{9}$ Intervensi semacam ini kerap dilakukan semata untuk keuntungan partai dan individu pejabat politik tertentu.

Kesadaran pentingnya kejujuran dalam pemilukada seringkali diabaikan sebagian Aparatur Sipil Negarakarena alasan sebagai-mana telah disinggung, padahal Aparatur Sipil Negara seharusnya netral dan melayani masyarakat. Keharusan netralitas tersebut ditegaskan Undang-Undang Nomor 5 Tahun 2014 tentang Aparatur Sipil Negara sebagai berikut.

Pasal 1 ayat (5): Manajemen Aparatur Sipil Negara adalah pengelolaan Aparatur Sipil Negara untuk menghasilkan Pegawai Aparatur Sipil Negara yang profesional, memiliki nilai dasar, etika profesi, bebas dari intervensi politik, bersih dari praktik korupsi, kolusi, dan nepotisme.

Pasal 9 ayat (2): Pegawai Aparatur Sipil Negara harus bebas dari pengaruh dan intervensi semua golongan dan partai politik.

Berdasarkan ketentuan tersebut Aparatur Sipil Negara pada dasarnya merupakan abdi negara dituntut setia dan taat pada Pancasila dan Undang-Undang Dasar (UUD) Tahun 1945 dalam menyelenggarakan tugas pemerintahan dan pembangunan. Hal itu karena kelancaran penyelenggaraan tugas pemerintah dan pembangunan tergantung pada Aparatur Sipil Negara sebagai unsur utama sumber daya manusia. Eksistensi Aparatur Sipil Negara sebagai abdi negara ditegaskan dalam Undang-Undang Nomor 43 Tahun 1999 sebagaimana diubah menjadi UndangUndang Nomor 53 Tahun 2010 tentang Pokok-Pokok Kepegawaian dan telah diperbaharui lagi pada tanggal 15 Januari 2014, menjadi Undang-Undang Nomor 5 Tahun 2014 tentang Aparatur Sipil Negara (UUASN).

Meski sudah ada larangan dalam Undang-Undang Nomor 5 Tahun 2014 tentang Aparatur Sipil Negara dan Peraturan Pemerintah Nomor 53 Tahun 2010 tentang Disiplin Pegawai Negeri Sipil, masih saja ada oknum aparatur sipil negara yang tetap melakukan kegiatan politik dalam pemilu,

\footnotetext{
${ }^{7}$ Azhari, Mereformasi Birokrasi Publik Indonesia, (Yogyakarta: Pustaka Pelajar, 2011), hlm. 94. 8 lbid.

9lbid.
} 
tentu dilakukan secara sembunyi-sembunyi agar terlepas dari pengawasan instansi/ badan yang berkompeten dalam pengawasan pemilukada dan pengawasan aparatur pemerintahan.

Penelitian terkait netralitas Aparatur Sipil Negara sudah pernah diteliti beberapa penulis lain. Fidel F. Gosal dkk pernah menulis tentangnetralitas Aparatur Sipil Negara Kantor Sekretariat Daerah Kabupaten Minahasa Tenggara pada pemilihan gubernur dan wakil gubernur Provinsi Sulawesi Utara tahun 2015. Dalam penelitiannya menyimpulkan: ${ }^{10}$

"1. Kurangnya pemahaman tentang batasan-batasan antara domain politik dan administrasi mengakibatkan para Aparatur Sipil Negara merasa kurang mengetahui jelas dan akhirnya memutuskan untuk tidak netral pada pemilukada serta kurangnya sosialisasi dari Panitia Pengawas Pemilu tentang pelanggaran-pelanggaran dan sanksi tegas pemilukada juga membuat para Aparatur Sipil Negara kurang mengetahui tentang apa sanksi yang diberikan jika melakukan pelanggaran.

2. Keterikatan Bupati pada partai politik yang mencalonkannya membuat dia berkomitmen untuk membantu partai tersebut dalam hal apapun, termasuk ketika partai tersebut mengusung calon gubernur dan wakil gubernur. Dari komitmen inilah yang membuat bupati mengintervensi dan mempengaruhi para Aparatur Sipil Negara mengarahkan pilihan pada calon yang dijagokannya dan melibatkan Aparatur Sipil Negara pada kampanye, memasang atribut pasangan calon atau bahkan memberikan perintah untuk ikut mengawasi hasil pemilihan pada hari pemilihan berlangsung.

3. Munculnya intervensi pimpinan terhadap bawahan menjadikan Aparatur Sipil Negara untuk tunduk dan taat pada atasan. Dari bentuk loyalitas inilah membuat bawahan memanfaatkan hal tersebut sebagai sebuah ajang mencari muka pada pimpinan hanya demi sebuah kepentingan pribadi, yaitu dipromosi-kan sebagai pejabat ataupun tetap aman dengan jabatan yang ada".

Tedi Sudrajat dan Agus Mulya Karsona pernah menyoal makna netralitas PNS dalam Undang-Undang Nomor 5 Tahun 2014 tentang Aparatur Sipil Negara. Dalam penelitiannya menyimpulkan "Konsep pembatasan didasar-kan pada konsepsi negara hukum demokratis yang berorientasi pada penerapan good governance guna

${ }^{10}$ Fidel F. GosalFlorence Daicy J. LengkongVery Y. Londa, Netralitas Aparatur Sipil Negara Kantor Sekretariat Daerah KabupatenMinahasa Tenggara Pada Pemilihan Gubernur Dan Wakil GubernurProvinsi Sulawesi Utara Tahun 2015, Jurnal Administrasi Publik UNSRAT, Volume 3, Nomor 400, Tahun 2016, hlm. 7-8. 
menciptakan perubahan kaidah perilaku yang menempatkan hubungan dinas publik dalam hukum kepegawaian. Adapun pembatasan hak politik bagi PNS dapat ditolerir sepanjang untuk menjamin pengakuan serta penghormatan atas hak dan kebebasan orang lain, dan untuk memenuhi tuntutan yang adil sesuai dengan pertimbangan moral, keamanan, dan ketertiban umum dalam suatu masyarakat demokratis. Atas dasar itu, maka pemaknaan terhadap netralitas adalah membatasi kewenangan dari PNS untuk tidak memihak dalam kegiatan politik". ${ }^{11}$

Tedi Sudrajat dan Sri Hartini pernah meneliti tentang rekonstruksi hukum atas pola penanganan pelanggaran asas netralitas PNS. Dalam penelitiannya menyimpulkan "Pelang-garan netralitas PNS merupakan isu hukum yang selalu terjadi di setiap penyelenggaraan Pemilu. Persoalan menahun ini akan dapat terselesaikan melalui komitmen pemerintah untuk membatasi PNS dalam kegiatan politik praktis. Kondisi ini menuntut akan rekonstruksi hukum terhadap pola penanganan pelanggaran PNS melalui 2 (dua) upaya, baik secara represif maupun preventif. Upaya represif dilakukan dengan cara membuat pengaturan tentang pola penanganan pelanggaran netralitas PNS dengan memperkuat pada fungsi koordinasi antara lembaga penyelenggara Pemilu, pengawas Pemilu, penyelenggara pemerintahan danlembaga yang memutuskan hukuman pelanggaran netralitas PNS. Adapun upaya preventif dilakukandengan cara penguatan peran pemerintah untuk mengantisipasi sifat pelanggaran, meliputi Pertama, menjaga iklim kondusif dan memberikan kesempatan kepada PNS untuk melaksanakan hak pilihnya secara bebas dengan tetap menjaga netralitas, serta tidak melakukan mobilisasi PNS dilingkungannya. Kedua, setiap jenjang jabatanmelakukan pengawasan terhadap bawahannya sebelum, selama dan sesudah masa kampanye". ${ }^{12}$

Sri Hartini pernah meneliti tentang penegakan hukum netralitas PNS. Kesimpulannya "netralitas PNS merupakan solusi untuk menyelesaikan permasalahan tentang keikutsertaan PNS dalam partai politik, yang selama Orde Baru dijadikan permainan politik oleh pemerintah yang berkuasa. Penegakan hukum terhadap netralitas PNS dalam realisasinya mengalami kesulitan, karena pengaturan mengenai penegakan hukum netralitas PNS yang diatur dalamUndang-Undang Nomor 43 Tahun 1999 tentang Perubahan atas UndangUndang Nomor 8 Tahun 1974 tentang PokokPokok Kepegawaian, yaituPasal 3 dan Penjelasan Umum I angka 6 memberi sanksi bagi PNS yang melanggarperaturan ini diberhentikan dari PNS. Peraturanini hanya mengatur bagi PNS yang menjadi anggota dan pengurus parpol, sehingga peraturan tersebut belum dapat menyelesaikan setiap

\footnotetext{
${ }^{11}$ Tedi Sudrajat dan Agus Mulya Karsona,Menyoal Makna Netralitas PegawaiNegeri Sipil dalam UndangUndang Nomor 5 Tahun 2014 tentangAparatur Sipil Negara, Jurnal MediaHukum, Volume23, Nomor 1, Juni 2016, hlm. 93.

${ }^{12}$ Tedi Sudrajat dan Sri Hartini, Rekonstruksi Hukum atas Pola Penanganan Pelanggaran Asas Netralitas Pegawai Negeri Sipil,Jurnal Mimbar Hukum, Volume 29, Nomor 3, Oktober 2017, hlm. 458.
} 
pelanggaran tentang netralitas. Jadi, bagi PNS yang tidak menjadi anggota danpengurus parpol, mereka lebih loyal, justrulepas dari sanksi". ${ }^{13}$

Hasil penelitian terdahulu tersebut mempunyai kemiripan dengan penelitian ini, yaitu sama-sama meneliti tentang netralitas Aparatur Sipil Negara, tetapi fokus permasalahannya berbeda. Penelitian Tedi Sudrajat dan Agus Mulya Karsona fokus tentang makna netralitas, Tedi Sudrajat dan Sri Hartini fokus tentang rekonstruksi hukum atas pola penanganan pelanggaran asas netralitas PNS, sedangkan Sri Hartini konsern tentang penegakan hukum netralitas PNS. Sementara, penelitian ini spesifiknya tentang netralitas Aparatur Sipil Negara dalam pemilihan Gubernur Riau tahun 2018. Oleh karena itu, penelitian ini jelas berbeda dengan penelitian terdahulu, sehingga akan menghasilkan suatu kebaruan (novelty).

Netralitas Aparatur Sipil Negara yang dimaksud dalam penelitian ini terkait keterlibatan Aparatur Sipil Negara pada proses politik dalam penyelenggaraan pemilukada yang telah berlangsung, sedang berlangsung dan akan berlangsung di Provinsi Riau tahun 2018. Adapun permasalahan dalam penelitian ini: Pertama, bagaimana netralitas Aparatur Sipil Negara dalam pemilihan Gubernur Riau tahun 2018? Kedua, bagaimana hambatan dan upaya mengatasi ketidaknetralan Aparatur Sipil Negara dalam pemilihan Gubernur Riau tahun 2018? Relevan dengan permasalahan tersebut maka penelitian ini penting dilakukan karena akan menjelaskan netralitas Aparatur Sipil Negara dalam pemilihan Gubernur Riau tahun 2018 serta menjelaskan hambatan dan upaya mengatasi ketidak-netralan tersebut.

\section{Metode Penelitian}

\section{Jenis Penelitian}

Jenis penelitian ini adalah penelitian hukum sosiologis. Penelitian hukum sosiologis menurut Badan Pembina Hukum Nasional (BPHN) lebih diarahkan pada suatu penelitian yang membahas tentang berlakunya hukum positif dan pengaruh berlakunya hukum positif terhadap kehidupan masyarakat serta pengaruh faktor-faktor non hukum terhadap terbentuknya ketentuanketentuan hukum.

Penelitian ini menggunakan metode pendekatan yuridis empiris, dengan maksud untuk menjelaskan netralitas Aparatur Sipil Negara dalam pemilihan Gubernur Provinsi Riau tahun 2018 termasuk hambatan dan upaya mengatasinya.

\section{Lokasi Penelitian}

Penelitian ini dilakukan di Provinsi Riau pemilukada Gubernur Provinsi Riau yang telah dilaksanakan pada tanggal 27 Juni 2018 yang lalu diikuti calon pertahana.

\section{Populasi dan sampel}

\section{a. Populasi}

Populasi dalam penelitian ini terdiri dari Badan Pengawas Pemilu (BAWASLU) Provinsi Riau, Pene-

${ }^{13}$ Sri Hartini, Penegakan Hukum Netralitas Pegawai Negeri Sipil (PNS), Jurnal Dinamika Hukum, Volume 9, Nomor 3 September 2009, hlm. 265-266. 
gakan Hukum Terpadu (GAKKUMDU)

Provinsi Riau, Kepala Badan

Kepagawaian Daerah (BKD)

Provinsi Riau dan Pengamat Politik.

b. Sampel

Jumlah dari masing-masing populasi di atas sebanyak 1 (satu) orang maka secara sensus keseluruhannya ditetapkan menjadi sampel.

\section{Sumber data}

a. Data primer

Data primer diperoleh dan dikumpulkan melalui informasi dari sampel secara langsung, mengenai hal-hal terkait dengan masalah yang diteliti.

b. Data sekunder

Data sekunder diperoleh melalui kepustakaan yang bersifat mendukung data primer.

c. Data tertier

Data tertier diperoleh melalui ensiklopedi dan yang sejenisnya yang berfungsi untuk mendukung data primer dan data sekunder.

\section{Teknik pengumpulan data}

a. Observasi

Teknik ini dilakukan dengan cara pengamatan langsung terhadap permasalahan yang diteliti.

b. Wawancara

Wawancara dilakukan secara terstruktur, yaitu tanya jawab antara penulis dengan sampel terikat dengan daftar pertanyaan yang telah disiapkan sesuai dengan arah permasalahan yang diteliti.

c. Kajian kepustakaan Metode pengumpulan data ini dilakukan melalui peran aktif penulis untuk membaca kepustakaan yang memiliki korelasi dengan permasalahan yang diteliti.

\section{Analisis data}

Data atau informasi yang diperoleh melalui teknik wawancara dikumpulkan dan disajikan dalam bentuk uraian kalimat (deskriptif), kemudian dianalisis secara kualitatif dan menghubungkannya dengan peraturan perundang-undangan, konsep, teori, pandangan para ahli serta data lainnya yang keseluruhannya relevan dengan penelitian dan disajikan secara deskritif. Dari pembahasan tersebut penulis menarik kesimpulan dalam penelitian ini dengan "metode induktif", yakni mengambil kesimpulan dari pernyataan yang bersifat khusus untuk ditarik kesimpulan secara umum.

\section{Pembahasan}

Netralitas Aparatur Sipil Negara dalam Pemilihan Gubernur Riau Tahun 2018

Penyelenggaraan pemilu memiliki dua faktor melekat yang tidak dapat dipisahkan, yaitu pelaksana dan kekuatan kontrol pelaksanaan pemilu. ${ }^{14}$ Untuk itu, kontrol terhadap Netralitas Aparatur Sipil Negara merupakan bagian dari elemen

${ }^{14}$ Zainal Arifin Hoesein, Pemilu Kepala Daerahdalam Transisi Demokrasi, Jurnal Konstitusi, Volume 7, Nomor 6, Desember 2010, hlm. 15. 
penyelenggaraan pemilu. Netralitas Aparatur Sipil Negara terkait pemilukada akan mendapat pengawasan serius. Pihak Deputi Sumber Daya Manusia (SDM) Kementerian Pemberdayaan Aparatur Negara dan Reformasi Birokrasi (Kemenpan-RB) dan pihak Kementerian Dalam Negeri (Kemendagri) telah bekerja sama dengan BAWASLU dan Komisi Aparatur Sipil Negara (KASN) untuk mengawasi netralitas Aparatur Sipil Negara. Sebelum pelaksanaan pemilukada serentak tanggal 27 Juni 2018 telah disosialisasikan agar Aparatur Sipil Negara yang tergabung dalam organisasi KORPRI bebas, aktif, profesional, netral, produktif, dan akuntabel.

Heru Haryo Prayitno selaku Kasubag Kepegawaian dan Umum BKD Provinsi Riau menambahkan bahwa Kemenpan-RB akan memberikan sanksi pada PNS atau Aparatur Sipil Negara bila terbukti terlibat dalam kegiatan politik dalam pemilukada, pemilihan presiden (pilpres) dan pemilihan legislatif (pileg). ${ }^{15}$

Undang-Undang Nomor 5 Tahun 2014 tentang Aparatur Sipil Negara mengatur secara tegas mengenai netralitas Aparatur Sipil Negara. Salah satu asas penyelenggaraan kebijakan dan manajemen Aparatur Sipil Negara adalah asas netralitas. Kedudukan pegawai Aparatur Sipil Negara adalah sebagai unsur aparatur negara yang harus bebas dari pengaruh dan intervensi semua golongan dan partai politik. Pegawai
Aparatur Sipil Negara berfungsi sebagai pelaksana kebijakan publik, pelayan publik serta perekat dan pemersatu bangsa. Aparatur Sipil Negara berperan sebagai perencana, pelaksana dan pengawas penyelenggaraan tugas umum pemerintahan dan pembangunan nasional melalui pelaksanaan kebijakan dan pelayanan publik yang profesional, bebas dari intervensi politik serta bersih dari praktik korupsi, kolusi dan nepotisme.

Ketentuan yang diatur dalam UndangUndang Nomor 5 Tahun 2014 memperkuat aturan lebih rendah terdahulu, seperti Peraturan Pemerintah (PP) Nomor 53 Tahun 2010 tentang Disiplin Pegawai Negeri Sipil jo Peraturan Kepala (Perka) Badan Kepawaian Negara (BKN) Nomor 21 Tahun 2010. Salah satu larangan bagi setiap PNS yang diatur dalam PP Nomor 53 Tahun 2010 dan Perka BKN Nomor 21 Tahun 2010, yaitu larangan memberikan dukungan kepada calon kepala daerah/wakil kepala daerah dengan cara memberikan surat dukungan disertai fotokopi Kartu Tanda Penduduk atau Surat Keterangan Tanda Penduduk sesuai peraturan perundang-undangan dan memberikan dukungan kepada calon kepala daerah/wakil kepala daerah, dengan cara:

1. Terlibat dalam kegiatan kampanye untuk mendukung calon kepala daerah/wakil kepala daerah.

2. Menggunakan fasilitas terkait dengan jabatan dalam kegiatan kampanye.

\footnotetext{
${ }^{15}$ Wawancara dengan Heru Haryo Prayitno, S.E., M.Si selaku Kasubag Kepegawaian dan Umum pada Badan Kepegawaian Daerah Provinsi Riau pada hari Selasa tanggal 3 Juli 2018 jam 10.00 Wib dikantornya Jalan Cut Nyak Dien, Kota Pekanbaru.
} 
3. Membuat keputusan dan/atau tindakan yang menguntungkan atau merugikan salah satu pasangan calon selama masa kampanye.

4. Mengadakan kegiatan yang mengarah pada keberpihakan terhadap pasangan calon yang menjadi peserta pemilu, sebelum, selama dan sesudah masa kampanye, meliputi pertemuan, ajakan, imbauan, seruan atau pemberian barang kepada PNS dalam lingkungan unit kerjanya, anggota keluarga, dan masyarakat. Pelanggaran terhadap larangan tersebut dapat dijatuhi hukuman disiplin sedang berupa penundaan kenaikan gaji berkala selama 1 tahun; penundaan kenaikan pangkat selama 1 tahun; dan penurunan pangkat setingkat lebih rendah selama 1 tahun. Bahkan hukuman disiplin berat berupa penurunan pangkat setingkat lebih rendah selama 3 tahun, pemindahan dalam rangka penurunan jabatan setingkat lebih rendah, pembebasan dari jabatan, pemberhentian dengan hormat tidak atas permintaan sendiri sebagai PNS; dan pemberhentian tidak dengan hormat sebagai PNS, dapat dijatuhkan bagi pelangaran terhadap larangan memberikan dukungan kepada calon kepala daerah/wakil kepala daerah, dengan cara menggunakan fasilitas yang terkait dengan jabatan dalam kegiatan kampanye dan/atau membuat keputusan dan/atau tindakan yang menguntungkan atau merugikan salah satu pasangan calon selama masa kampanye.

Satu dinamika dan masalah penting dalam pemilihan Gubernur Riau tahun 2018 yang lalu terkait netralitas PNS yang kini disebut Aparatur Sipil Negara. Memang dari segi jumlah Aparatur Sipil Negara di suatu daerah termasuk di Provinsi Riau dalam Pemilukada serentak tahun 2018 lebih kecil bila dibandingkan dengan jumlah daftar pemilih tetap (DPT). Data terakhir yang dirilis Kementerian Pendayagunaan Aparatur Negara dan Reformasi Birokrasi (KemenPAN-RB) menyebutkan, jumlah Aparatur Sipil Negara se-Indonesia kurang dari 4.5 juta orang atau hanya berkisar 1,7 \% dari sekitar 240 juta jiwa/penduduk Indonesia. Tetapi, jangan lupa Aparatur Sipil Negara rata-rata memiliki status sosial yang tinggi, sehingga dukungan mereka ke satu pasangan calon (paslon) sangat potensial memiliki efek berlipat di masyarakat peserta pemilih.

Pemilukada serentak tahun 2018 yang diselenggarakan di 17 provinsi, salah satunya di Provinsi Riau atau khusus bagi kepala daerah dan wakil kepala daerah yang akan mengakhiri masa jabatannya pada bulan Juli 2018. Adapun pemilukada serentak merupakan upaya untuk menciptakan local accountability, political equity dan local responsiveness. Dengan begitu, demokratisasi di tingkat lokal terkait erat dengan tingkat partisipasi dan relasi kuasa yang dibangun atas dasar pelaksanaan asas kedaulatan rakyat. Selain itu, hasil pemilukada juga harus mampu mengantarkan masyarakat pada kondisi sosial, politik dan ekonomi yang lebih baik. Pemilukada yang baik akan melahirkan pemerintahan yang baik. Pemilukada yang diselenggarakan secara lebih profesional, demokratis, akan memberikan dampak nyata terhadap perubahan politik. 
Meskipun demikian, dalam praktiknya pemilukada melahirkan berbagai konflik diantaranya dipicu oleh masalah administrasi data pemilih, netralitas penyelenggara pemilu, serta kurangnya kepatuhan peserta pemilukada dan partai politik terhadap peraturan yang berlaku. Pemilukada serentak sebagai agenda politik nasional menuju demokratisasi dapat berjalan secara substansi dan tidak sekedar ritual prosedur semata.

Berdasarkan hasil wawancara langsung penulis dengan Rusidi Rusdan Lubis selaku Ketua BAWASLU Provinsi Riau menjelaskan bahwa pada pemilihan Gubernur Riau pada tanggal 27 Juli 2018 berjalan lancar dan aman. Terkait dengan netralitas Aparatur Sipil Negara menurut pantauan dan temuan di lapangan cukup netral. Hal ini karena tidak ada laporan masuk ke BAWASLU terkait ketidaknetralan Aparatur Sipil Negara baik Aparatur Sipil Negara dari Pemerintah Provinsi Riau maupun dari Pemerintah kabupaten/kotadi Riau. ${ }^{16}$

Pendapat yang sama juga dikemukakan BKD Provinsi Riau dalam wawancara secara langsung dengan penulis. Pihak BKD tersebut menjelaskan bahwa Aparatur Sipil Negara cukup netral, karena tidak ada laporan keterlibatan Aparatur Sipil Negara mendukung pasangan calon tertentu mulai dari tahapan kampanye sampai dengan pencoblosan tanggal 27 Juni 2018. Hal ini sejalan dengan Surat Edaran Menteri Dalam Negeri agar seluruh Aparatur Sipil Negara menjaga netralitas dalam penyeleng-garaan pemilukada serentak 2018 termasuk dalam pilpres dan pileg serentak 2019. Surat Edaran tersebut menyebutkan akan memberikan sanksi tegas bagi Aparatur Sipil Negara bila terbukti tidak netral, mulai dari surat teguran hingga pemberhentian dari jabatan. ${ }^{17}$

Tidak berbeda dengan pendapat di atas, pihak GAKKUMDU Provinsi Riau juga berpendapat sama. Dalam pemilihan umum Gubernur Provinsi Riau tahun 2018 pihak GAKKUMDU Provinsi Riau tidak ada menerima laporan dan temuan terkait ketidaknetralan Aparatur Sipil Negara. Kalau ada laporan masuk maka GAKKUMDU pasti akanmemproses sesuai dengan peraturan perundang-undangan yang berlaku. ${ }^{18}$

Berbeda dengan pendapat di atas, pengamat politik Alisyahbana Ritonga selaku Direktur Eksekutif Lembaga Kajian Hukum dan Demokrasi (LKHD) menjelaskan bahwa terkait netralitas Aparatur Sipil Negara dalam pemilihan Gubernur Riau tahun 2018 sulit dibuktikan. Menurutnya, jika betul-betul didalami pasti banyak ditemukan fakta Aparatur Sipil Negara yang tidak netral atau berpihak pada salah satu calon Gubernur

\footnotetext{
${ }^{16}$ Wawancara dengan Niel Antariksa, S.H., M.H. selaku Tim GAKKUMDU pada hari Selasa tanggal 3 Juli 2018 jam 14.00 Wib dikantornya Jalan Adi Sucipto No. 284 (Komplek Transito) Pekanbaru.

${ }^{17}$ Wawancara dengan Heru Haryo Prayitno, S.E., M.Si selaku Kasubag Kepegawaian dan Umum pada Badan Kepegawaian Daerah Provinsi Riau pada hari Selasa tanggal 3 Juli 2018 jam 10.00 Wib dikantornya Jalan Cut Nyak Dien, Kota Pekanbaru.

${ }^{18}$ Wawancara dengan Niel Antariksa, S.H., M.H. selaku Tim GAKKUMDU pada hari Selasa tanggal 3 Juli 2018 jam 14.00 Wib dikantornya Jalan Adi Sucipto No. 284 (Komplek Transito) Pekanbaru.
} 
Riau. Keadaan ini dapat dinamakan ketidaknetralan terselubung. Ketidaknetralan ini sangat sulit dibuktikan. Ukuran ketidaknetralan tidak tepat jika hanya diukur berdasarkan laporan masuk. Manakala seorang Aparatur Sipil Negara menduduki jabatan eselon, sepertikepala bagian atau kepala dinasmaka akan sulit menghindar dari keterikatan dengan pasangan calon khususnya calon incumbent/petahana. Bahkan sering terjadi lobi politik atau bergaining politik terhadap Aparatur Sipil Negara akan mendapat jabatan yang strategis, jika calon pertahana yang didukung menang.

Hal inilah yang membuat Aparatur Sipil Negaratertentu sulit lepas dari ketidaknetralan dalam pemilihan Gubernur Riau tahun 2018 yang lalu. Padahal peraturan perundang-undangan melarang Aparatur Sipil Negara terlibat berpolitik aktif sebagaimana ditentukan dalam UndangUndang Nomor 5 Tahun 2014 tentang Aparatur Sipil Negara yang memperkuat aturan sebelumnya, yaitu PP Nomor 53 Tahun 2010 tentang Disiplin PNS jo Perka BKN Nomor 21 Tahun 2010.

\section{Hambatan dan Upaya Mengatasi Ketidak- netralan Aparatur Sipil Negara dalam Pemilihan Gubernur Riau Tahun 2018}

Ketua BAWASLU Provinsi Riau menjelaskan bahwa hambatan mengatasi ketidaknetralanAparatur Sipil Negara disebabkan lemahnya penegakan hukum/ punisment. Hukuman bagi pelanggar tidak maksimal sehingga tidak ada efek jera. Bagi pelakunya dianggap sebagai sesuatu yang lumrah. Adanya suatu sistem simbiosis mutualisme baik Aparatur Sipil Negara maupun kandidat dalam mencapai kepentingan bersama. Apalagi kalau kandidat berasal dari pertahana atau kandidat yang berasal dari kalangan birokrasi. Walaupun Aparatur Sipil Negara seharusnya netral, tetapi tetap saja dimanfaatkan pertahana untuk meraih suara. $^{19}$

Tim GAKKUMDU Provinsi Riau menjelaskan bahwa Aparatur Sipil Negara sebenarnya tidak buta politik dan memahami perkembangan politik sehingga tidak mudah dipengaruhi. Netralitas Aparatur Sipil Negara dalam pemilukada dapat dilihat dari dua aspek. Pertama, Aparatur Sipil Negara yang mencalonkan diri atau dicalonkan sebagai kandidat kepala daerah. Kedua,Aparatur Sipil Negara yang terlibat karena dilibatkan atau melibatkan diri. Hal ini menjadi suatu hambatan untuk menjaga netralitas Aparatur Sipil Negara itu sendiri.Tim GAKKUMDU Provinsi Riau menambahkan sebagai bagian dari birokrasi maka Aparatur Sipil Negara cenderung memihak kepada penguasa. Hal ini karena dorongan untuk memperbaiki nasib dan memperoleh kedudukan yang lebih tinggiatau karena ambisi pribadi.

Tim GAKKUMDU Provinsi Riau menambahkan netralitas Aparatur Sipil

\footnotetext{
${ }^{19}$ Wawancara dengan RUSIDI RUSDAN LUBIS, S.Ag., M.Pd.I. selaku Ketua BAWASLU Provinsi Riau pada hari Selasa tanggal 3 Juli 2018 jam 13.30 Wib dikantornya Jalan Adi Sucipto Nomor 284 (Kawasan Komplek Transito), Kota Pekanbaru.
} 
Negara dalam pemilihan Gubernur Riau tidak berjalan sepenuhnya. Meskipun tidak ada laporan. Adapun bentuk ketidaknetralan, seperti menghadiri acara deklarasi, syukuran dan acara di kediaman pasangan calon tertentu. Secara kasat mata, pengerahan Aparatur Sipil Negara agar berpihak terhadap salah satu kandidat tidak ada ditemukan dalam pemilihan umum gubernur Riau tanggal 27 Juni 2018 yang lalu. ${ }^{20}$

Terkait netralitas Aparatur Sipil Negara pihak BKD Provinsi Riau menjelaskan beberapa hambatan dalam menjaga netralitas Aparatur Sipil Negara dalam pemilihan umum Gubernur Riau, sebagai berikut:

1. Masih kuatnya primordialisme politik, dimana ikatan kekerabatan, politik balas budi, keinginan membangun pemerintahan berbasis keluarga, mencari rasa aman, dan perilaku oportunis birokrat.

2. Mekanisme check and balance belum menjadi budaya dan belum dilaksanakan dengan baik.

3. Kekuasaan yang dimiliki politisi cenderung untuk korup.

4. Rendahnya kedewasaan partai politik dan ketergantungan tinggi terhadap birokrasi.

5. Kondisi kesejahteraan aparat birokrat atau Aparatur Sipil Negara di daerah yang rendah cenderung melahirkan praktik rent seeking melalui aktivitas politik tersembunyi demi mendapat income tambahan;

6. Perangkat aturan yang belum jelas dan mudah dipolitisasi, seperti lemahnya instrumen pembinaan pegawai, kode etik belum melembaga, adanya status kepala daerah sebagai pembina kepegawaian, dan rangkap jabatan kepala daerah dengan ketua umum partai politik.

Terkait hambatan ketidaknetralan Aparatur Sipil Negara dalam Pemilihan Umum Gubernur Provinsi Riau tersebut berikut ini dijelaskan tentang upaya mengatasinya. Menurut Ketua BAWASLU Provinsi Riau upaya untuk menjaga netralitas Aparatur Sipil Negara dapat dilakukan dengan cara menerapkan aturan main yang jelas bagi Aparatur Sipil Negara, sistem pola pengangkatan dan pemberhentian pejabat karier, perubahan mindset dan peningkatan profesionalitas bagi Aparatur Sipil Negara, penegakan hukuman/punisment bagi Aparatur Sipil Negara yang melanggar aturan.

BKD Provinsi Riau menjelaskan bahwa upaya yang dapat dilakukan untuk mengatasi ketidaknetralitan Aparatur Sipil Negara dalam Pemilukada Provinsi Riau,sebagai berikut. ${ }^{21}$

1. Para pejabat pembina kepegawaian atau penjabat/pelaksana tugas kepala daerah dan pejabat yang

\footnotetext{
${ }^{20}$ Wawancara dengan Niel Antariksa, S.H., M.H. selaku Tim GAKKUMDU pada hari Selasa tanggal 3 Juli 2018 jam 14.00 Wib dikantornya Jalan Adi Sucipto No. 284 (Komplek Transito) Pekanbaru.

${ }^{21}$ Wawancara dengan Heru Haryo Prayitno, S.E., M.Si selaku Kasubag Kepegawaian dan Umum pada Badan Kepegawaian Daerah Provinsi Riau pada hari Selasa tanggal 3 Juli 2018 jam 10.00 Wib dikantornya Jalan Cut Nyak Dien, Kota Pekanbaru.
} 
berwenang pada instansi pemerintah, untuk melaksanakan dan mensosialisasikan Surat Menteri PANRB dengan sebaik baiknya.

2. Kepada para pejabat pembina kepegawaian atau penjabat/ pelaksana tugas kepala daerah dan pejabat yang berwenang pada instansi pemerintah, wajib:

a. Mengupayakan terus menerus terciptanya iklim yang kondusif dan memberikan kesempatan kepada PNS untuk melaksanakan hak pilihnya secara bebas dengan tetap menjaga netralitas.

b. Melakukan pengawasan kepada bawahannya sebelum, selama, dan sesudah masa kampanye agar tetap menaati peraturan perundang undangan dan ketentuan kedinasan yang berlaku.

c. Mengambil tindakan dengan melaporkan dan mengkoordinasikan kepada BAWASLU Provinsi dan Panitia PengawasPemilu (PANWASLU) Kabupaten/Kota secara berjenjang sesuai dengan kewenangannya yang diatur dalam peraturan perundang-undangan.

d. Seluruh Aparatur Sipil Negara agar tetap menjaga kebersamaan dan jiwa korps dalam menyikapi situasi politik yang ada dan tidak terpengaruh untuk melakukan kegiatan yang mengarah pada keberpihakan/indikasi ketidaknetralan.

\section{Simpulan}

1. Netralitas Aparatur Sipil Negara dalam pemilihan Gubernur Riau tidak berjalan sepenuhnya. Ketidaknetralan terjadi sebelum masuk masa kampanye dan selama masa kampanye. Adapun bentuk ketidaknetralan, seperti menghadiri acara deklarasi, syukuran dan acara di kediaman pasangan calon tertentu. Pengerahan Aparatur Sipil Negara agar berpihak terhadap salah satu kandidat tidak ada ditemukan dalam pemilihan umum gubernur Riau tanggal 27 Juni 2018 yang lalu.

2. Faktor penghambat netralitas Aparatur Sipil Negara dalam pemilihan Gubernur Riau disebabkan pengaruh tekanan (intervensi) dari calon pertahana. Upaya mengatasi agar Aparatur Sipil Negara tetap netral dalam pemilihan Gubernur Riau dapat dilakukan dengan memberikan sanksi sesuai PP Nomor 53 Tahun 2010 tentang Displin Pegawai Negeri Sipil.

\section{Saran}

1. Pemerintah Provinsi Riau dan BKD Provinsi Riau hendaknya meningkatkan pengawasan terhadapAparatur Sipil Negara agar selalu menerapkan jati dirinya sebagai abdi negara dan abdi masyarakat, sehingga tidak terlibat dalam politik praktis.

2. Agar netralitas Aparatur Sipil Negara dalam setiap event politikbisa dijaga maka hendaknya penegakan hukum dapat dijalan secara konsisten 


\section{Referensi}

Azhari. 2011. Mereformasi Birokrasi Publik Indonesia. Yogyakarta: Pustaka.

Fidel F. Gosal Florence Daicy J. Lengkong Very Y. Londa. Netralitas Aparatur Sipil Negara Kantor Sekretariat Daerah Kabupaten Minahasa Tenggara Pada Pemilihan Gubernur Dan Wakil Gubernur Provinsi Sulawesi Utara Tahun 2015. Jurnal Administrasi Publik UNSRAT. Volume 3. Nomor 400. Tahun 2016. Miftah Thoha. 2012. Birokrasi Pemerintahan dan Kekuasaan di Indonesia. Yogyakarta: Thafa Media.

Moh. Busro Muqaddas dkk (Penyunting). 1992. Politik Pembangunan Hukum Nasional. Yogjakarta: UII Press.

Muhammad Alwan Yamin. 2013. Netralitas Pegawai Negeri Sipil dalam Pemilihan Umum Kepala Daerah di Kabupaten Takalar. Makasar: Universitas Hasanuddin.
Riris Katharina. Netralitas Birokrasi dalam Pemilu Legislatif 2009 (Studi di Kabupaten Labuhan Ratu). Jurnal IImiah. edisi Kajian. 2010.

Sri Hartini. Penegakan Hukum Netralitas Pegawai Negeri Sipil (PNS). Jurnal Dinamika Hukum. Volume 9. Nomor 3 September 2009.

Tedi Sudrajat dan Agus Mulya Karsona. Menyoal Makna Netralitas Pegawai Negeri Sipil dalam Undang-Undang Nomor 5 Tahun 2014 tentang Aparatur Sipil Negara. Jurnal Media Hukum. Volume 23. Nomor 1 Juni 2016.

Tedi Sudrajat dan Sri Hartini. Rekonstruksi Hukum atas Pola Penanganan Pelanggaran Asas Netralitas Pegawai Negeri Sipil. Jurnal Mimbar Hukum. Volume 29. Nomor 3. Oktober 2017.

Zainal Arifin Hoesein, Pemilu Kepala Daerahdalam Transisi Demokrasi, Jurnal Konstitusi, Volume 7, Nomor 6, Desember 2010. 